\title{
Contributions of Bacău to the economic literature and culture - The life and work of Professor Vasile Pătruț
}

\author{
Mihai Deju, Ph.D, "Vasile Alecsandri” University of Bacău, Romania
}

\begin{abstract}
The economic culture and accounting theory in Bacău area has its beginnings in the setting up of the first practical school of agriculture, by Ion Ionescu de la Brad, who included in the curriculum an accounting course, as well.

Over the years, the economic education of Bacău area education has evolved from "The School of Accounting and Co-operative Education" (1919) to the modern economic higher education, in our days.

During an important period of the evolution of education and culture in Bacău area, Professor Vasile Pătruţ is present, having a significant contribution to the accounting theory, teaching and practice in Bacău.
\end{abstract}

\section{Key-words}

contributions of Bacău, economic literature and culture.

\section{JEL Code: $A 11$}

The evolution of economic literature and culture in Bacău area can be approached only in strong connection with the emergence and development of education, in this area.

If we speak of tradition in Bacău, in terms of economic culture and accounting theory, we must mention that it finds its beginnings towards the end of the $19^{\text {th }}$ century, more precisely in 1870, when Ion Ionescu de la Brad, the founder of the Romanian modern agriculture, set up, on his own land, a model farm and a practical agriculture school, which included in the curriculum a course of "Phytology, Zootechny, Rural Economics and Accounting".

Later, at the beginning of the $20^{\text {th }}$ century, more precisely in 1919 , when the position of economic and commercial centre of Bacău allowed the development of popular banks, the School of Accounting and Co-operative Education was set up in Bacău - together with the Group of popular banks in Bacău. The same year, the Elementary School of Commerce in Bacău was also founded with the help of the Chamber of Commerce and Industry, and especially of its chairman, George Florescu, an exponent of Bacău business environment, who has strived to meet the requirements of merchants and industry employers in the area. This school was recognized by the Ministry of Public Instruction in 1921.

Shortly after, in 1925, the Superior School of Commerce was set up, a school that, only three years after, together with the Elementary School of Commerce, will turn into the Commercial High school of Bacău. It will operate uninterruptedly until the education reform in 1948 when it changes in the Technical school of Economic Administration and will operate until 1955, when the professional and economic education will be abolished in Bacău.

After a break of five years, in 1960, the commercial and accounting education in Bacău reappears under the dome of a Commercial School Group, which had in its structure the Professional Commercial School and the Post-secondary School of Commercial Technique, preparing particularly accountants for commerce. 
The large number of enterprises in Bacău economy and the increased demand of staff with average economic training, in the post-collectivization period, caused the setting up, in 1966, of the Economic High school in Bacău, whose purpose was the training of accountants, planners, statisticians and merceologists.

The Commercial School Group and The Economic High School merged in 1972, in one school institution that will bear in time, more names, now being called "Ion Ghica" National College, though it would have been more appropriate to call it "Ion Ionescu de la Brad", according to the tradition.

As we speak of Bacău traditions concerning the accounting theory, we must mention that in the curricula of all the above school units, accounting and economic disciplines have always appeared as subjects of study of the first rank.

Among the mentors who honoured with competence and professionalism the economic disciplines, we mention here only a few: Prof. Gh. Manolescu, between the years 1924-1952, Prof. Nicolae Vânătorul 1949-1955, and 1962-1972, Prof. Vasile Pătruţ during the period 1966-1991, Prof. Vasile Gavriliu 1966-1991, Prof. Elena Mocanu 1968-1994 and others to whom I ask forgiveness for missing to mention their names.

A qualitative leap, in the field of Bacău economic education, occurred in the postrevolutionary period, and since 1990 we can speak of the existence of higher economic education in the public University of Bacău, by means of the section Tourism-Services and since 1991, Marketing section.

In the autumn of 1992, in reply, the first year courses were opened at "George Bacovia" private university, founded by the Foundation with the same name, having an economic section in its structure.

Since 1997, at the public University of Bacău, the economic education has diversified, and a new specialization, "Accounting and Managerial Informatics", was set up by the initiative of Professor Vasile Pătruţ.

I have made this retrospective of economic education in Bacău, since Professor Vasile Pătruţ has been present, by his contributions, to the accounting theory, teaching and practice in Bacău, for more than forty-four years.

As a creator of economic culture and, especially, of accounting theory, his work needs be known, because, essentially, culture is based, at each stage of its existence, on the creation of predecessors, and ignoring the past inevitably leads to the weakening of the present creative forces.

Furthermore, we will proceed to the presentation of the human and the mentor Vasile Pătruţ, because, if you really want to know someone's personality, you should go back to the origins. Thus, by analysing the past, we consolidate the present and discover the future.

The presentation of Professor Vasile Pătruţ's life has as bibliographic basis the work entitled "Professor Vasile Patrut. A life devoted to economic education and scientific research", developed by a collective of authors, members of the Department of Accounting and Finance from the Faculty of Economic Sciences of the "Vasile Alecsandri "University of Bacău (the work represents mainly an autobiography, being coordinated by its main character himself).

Vasile Pătruţ was born on $18^{\text {th }}$ of December 1940, in Boteşti village of the commune with the same name, in the former Roman County, today called Neamţ County, and coming from a family of farmers to whom God gave two children. The father, Neculai Pătruţ, dies on the front in April 1944, so only the mother, widow Catrina will take care of the growth and education of the two children.

The student Vasile Pătruţ followed the four compulsory primary grades at the school in his native village, being one of the best students. Following the advice of the teacher Neculai Bernevic, the mother registered her son to attend the $5^{\text {th }}-7^{\text {th }}$ grades, at the only school in the commune where the second education cycle functioned. In this cycle of education, the student Vasile Patrut is has very good results.

His love, at first for "the art of accounting", and later for "the science of accounting" appeared in this period, when, in the summer holidays, between the $6^{\text {th }}$ and the $7^{\text {th }}$ grades, 
and after graduation, as well, the teenager Vasile N. Pătruţ works as junior accountant at the Consumption Cooperative in the commune, with his uncle, Vasile Iordache Pătruţ, president of the cooperative.

In the autumn of 1956, the teenager Vasile Pătrut is sent, with a scholarship of the District Union of Consumption Cooperatives, to be trained for four years, in the field of accounting, at the Technical School of Cooperation in Buzău. In 1960, the young Vasile Pătruţ, graduate of the Technical School of Cooperation, was assigned chief accountant at the Consumption Cooperative, Pildeşti, in Roman district, where, as a young professional and intellectual, he had the mission to help increase the level of civilization in his native rural area, as a contractual obligation towards the unity funding of studies.

After two months of work, July and august 1960, at his first official job, the Consumption Cooperative Pildesti, with the money earned (650 lei per month), the young Vasile Patrut travels to Bucharest, to be present, in September 1960, at the entrance examination, to the unique economic institution of higher education in the country, the "V.I. Lenin" Institute of Economic Sciences in Bucharest, the current Academy of Economic Studies.

Following the contest (two written examinations: Mathematics and Geography, three oral examinations: Geography, History, Constitution), Vasile Pătruţ is declared admitted as a fellow student, with a high average, since at the beginning of the courses, he was named, by the dean of the faculty, professional responsible of the group. This is how his life as a student in Bucharest began, the most beautiful period of the professor's life, as he himself said in various circumstances.

In this period, the young Vasile Pătruţ showed an attraction for study and scientific research, acting as a member or a leader in students' scientific circles, such as the accounting circle and the analysis of the enterprise economic activity one, the latter under the guidance of Professor Alexandru Gheorghiu who was also the coordinator of his graduation paper. We can conclude that for the student Vasile Pătrut, the studentship is the period when the passion for the "science of accounting" was born, culminating, afterwards, with the award of the title of Doctor in the field of Accounting.

Upon graduation, in 1965, as Vasile Patrut was among the best students, he would have wished to remain in higher education, in Bucharest, where his wife still had two years of study. However, there was no such possibility in that academic year, and he had the take the position of teacher at the School in Buzău, where he had been student five years before. Here, he worked only for one school year, because, starting with September 1966 he transferred closely to his native place, as teacher of accounting and finance at the Commercial Technical School in Bacău.

After obtaining the first degree in education, in 1968, Professor Vasile Pătrut transferred to the Economic High school in Bacău, where his wife, the teacher Frăsina Patrut, came, as well, At the Economic High school in Bacău, later the Economic College, Professor Vasile Patrut worked for 21 years, until 1991, when he was called upon to contribute to the creation the economic higher education in Bacău.

In those years, which coincided with a large part of his life, Professor Pătruţ contributed to the formation of many generations of accountants with secondary education and he himself made achievements in his professional, social and family life. Professor Vasile Pătruţ taught during these years, particularly accounting, and other economic disciplines, as well: Finance, Business Analysis, Foreign Trade, the Mechanization and Automation of the work, and Economic Informatics.

Permanently concerned about the development of the accounting theory and practice and also about his own scientific and academic training, Professor Vasile Pătruţ participated in various training programmes organized in the country, he obtained the second teaching degree in 1973 and the first teaching degree in 1979, and in 1988 he was conferred the academic title of Doctor in economics, Accounting section, at the Academy of Economic Studies in Bucharest, under the guidance of his well known Professor Victor Puchiţă. 
As we mentioned above, in 1991, Professor Vasile Pătruţ answered the solicitation of the public university, and, following a contest, he occupied the position of associate professor for the Accounting discipline. As the only professor with superior didactic degree, among the economists from the University of Bacău, he is named Head of the Department of Economics and Social Sciences, in 1995, and in 1996 he obtains the title of Professor

From this position, Professor Vasile Pătruț, assumes the difficult and noble task of setting up a team of teachers, by attracting specialists from production with vocation for higher education, by determining graduates, of the most valuable economic students of higher education in Bacău to choose the career in higher education, as well as by working with a number of specialists, recognized practitioners, whose expertise and scientific attire have put their long-term mark on the economic education at the "Vasile Alecsandri" University of Bacău. Thus, there began the process of consolidation and development of the economic higher education which was born in Bacovia's native town, expanding the range of specializations of the public university in Bacău.

In the autumn of 2008, Professor Vasile Pătruţ retired, but still worked as an associate professor in the academic year 2008-2009, particularly at the master programme in Business Accounting and Audit, that he himself set up and organised.

Although he had some offers from other educational institutions, he preferred to retire, considering that the time had come to write more for posterity, sharing his knowledge and experience as an accounting teacher, of nearly half a century, dedicating himself to the establishment and publication of scientific papers and memoirs. Thus, Professor Vasile Pătruţ proves that, from a prodigious activity, one can retire only formally, when the meaning of life was the passion for permanent study and research.

Over the years, the scientific research activity of Professor Vasile Pătruţ has resulted in the development of many works and studies published in publishing houses or journals, textbooks, for economic high schools or for economic higher education. Synthesizing, Professor Vasile Pătrut has developed as a single author, or co-author, along with his colleagues from the Department: 14 books - most of the books published in publishing houses recognized by CNCSIS, over 70 studies and articles published in journals recognized nationally and internationally; 5 works of applied research; 33 books, courses and other works with didactic character. To these there are added two books of memoirs and two documentaries in the form of brochures, carried out as the only author or in collaboration.

Among the scientific books in the field of accounting, we mention: „Contabilitatea financiară a întreprinderii" ("The Financial Accounting of the Enterprise") published in two editions - 1994 and 2003; „Manualul expertului contabil şi a contabilului autorizat" ("The Certified Public Accountant Manual") published in six editions between 1995 and 2002; „Contabilitatea intreprinderii” (“Enterprise Accounting”) - 2002; „Contabilitate şi diagnostic financiar" ("Accounting and financial diagnosis") - two editions: 2005 and 2010; "Gestiunea şi contabilitatea unor activităţi economice cu caracter deosebit")"The management and accounting of special economic activities") - 2005; "Didactica disciplinelor economice"("Didactics of economic disciplines") -2008; etc.

The above mentioned works, as well as the other ones, represent a great contribution to the development of accounting theory and practice, being meant for students of economics and the interested parties to take full advantage of accounting knowledge in view of managing units in which they are involved as managers, investors or business partners. Some of the works were the bibliographical source for exams organized by CECCAR for improving the quality of chartered accountant or certified public accountant, while others can be the basis for research in the field of accounting.

In his capacity of teacher of accounting, for 44 years, including 26 years in high-school education and 18 years in higher education, Professor Vasile Pătruţ contributed along with his collaborators to the formation of over 25 generations of accountants with secondary education and over 15 generations of economists with higher education. At the same time, he contributed to the formation of four promotions of graduates with a master degree in 
Business Accounting and Audit and 4 master promotions in Marketing Strategies and Communication in Public Administration. He participated in his capacity as scientific reviewer, as a member of the Board of advisers, at the evaluation of several theses in the field of accounting. As a didactician of accounting, as well as head of professional departments, at college and high school, he also contributed to the formation of a significant number of teachers in the field of accounting and other economic disciplines.

Professor Vasile Pătruţ himself, as head of the Chair, in his report on the work made during his mandate between 2004 and 2008, asserts that ... "after a lifetime dedicated to the economic education (43 years), of which 18 years of higher education in the University of Bacău, i.e. 13 years as head of the Chair, I can say that I am satisfied with what I have done and what I leave behind. It remains that you, my younger colleagues, most of which were my students, to make further progress, at an even higher level of accounting education, in the service of which I have dedicated almost all my life. I wish you good luck in your future work, may you be united and not forget your forefathers."

In sign of respect for the entire activity, we can conclude that Professor Vasile Pătruţ, throughout his career, has been identified with the school, remaining in the memory of his students as the model of high school teacher and the embodiment of the professor. His dedication to the school and pupils or students remains exemplary and admirable. Many of his collaborators over the years can be proud to have met him and are thankful for the altruism of the professor who has proved, most of the time, both mentor and colleague, supporter in training, in research, professional development and career. If the large number of accountants and economists trained at Bacău became known in various areas of activity, this is greatly due to the economic school of Bacău and to its teachers.

Professor Vasile Pătruţ has a special contribution to the development of the Romanian economic education, a decisive contribution to the creation and consolidation of the economic higher education in Bacău, especially of the accounting one, which, in fact, he sets up and develops, together with other collaborators.

The "Vasile Alecsandri" University of Bacău, through the Faculty of Economics, has Professor Vasile Pătruţ who laid the cornerstone and built in Bacău the school of economists and accountants, leaving to his followers the moral duty to continue and develop the economic education in Bacău at European and international standards.

When we make statements or think about the contribution of Professor Vasile Pătruţ to the economic culture and especially to that of "the science of order", one of the most beautiful creations of the mind - according to a great philosopher, we cannot but include him in the science area of Bacău, along with other valuable creators of economic culture and literature. We refer here to the remarkable group of collaborators of Professor Vasile Pătruţ within the Department of Accounting - Finance of the "Vasile Alecsandri" University of Bacău authors of innumerable works, to the prestigious specialists in the field of accounting from the "George Bacovia" University of Bacău, as well as other personalities of accounting theory and practice, which Bacău has offered.

In this context of cultural-scientific space of Bacău, we discover Professor Vasile Pătruţ and consider him a true master of accounting in Bacău, who will be a reference model for future generations of students, economists, practitioners, researchers, creators of accounting literature.

\section{Bibliografie}

1. Pătruţ, V. (coord.), Deju, M., Pătruţ, B., Rotilă A., Țuţuianu, I. (2010), Profesorul Vasile Pătruţ. O viaţă dedicată învăţământului economic şi cercetării ştiinţifice - autobiografie şi biografie, Alma Mater Publishing House, Bacău

2. Rusu, D., Petriş, R., Horomnea, E. et.al. (1991), Fra Luca di Borgo şi Doctinele contabilităţii în cultura economică romanească, Junimea Publishing House, Iaşi 